\title{
Neonatal hyperbilirubinemia: Background and recent literature updates on the diagnosis and treatment
}

\author{
H. NAWAZ ${ }^{1 *}\left(\mathbb{D}\right.$, M. $\operatorname{ASLAM}^{1}$ and T. REHMAN ${ }^{2}$ \\ ${ }^{1}$ Department of Biochemistry, Bahauddin Zakariya University, 60800, Multan, Pakistan \\ ${ }^{2}$ Department of Chemistry, The Women University Multan, 60000, Multan, Pakistan
}

Received: January 18, 2021 Accepted: April 26, 2021

Published online: June 21, 2021

๑ 2021 Akadémiai Kiadó, Budapest

\begin{abstract}
Hyperbilirubinemia or jaundice has been studied by many researchers because of its diverse causes and potential for toxicity especially in the neonate but to a lesser extent beyond the neonate as well. Several studies have been performed on the normal metabolism and metabolic disorders of bilirubin in last decades of the $20^{\text {th }}$ century. The recent advancement in research and technology facilitated for the researchers to investigate new horizons of the causes and treatment of neonatal hyperbilirubinemia. This review gives a brief introduction to hyperbilirubinemia and jaundice and the recent advancement in the treatment of neonatal hyperbilirubinemia. It reports modifications in the previously used methods and findings of some newly developed ones. At present, ample literature is available discussing the issues regarding hyperbilirubinemia and jaundice, but still more research needs to be done.
\end{abstract}

\section{KEYWORDS}

bilirubin, neonatal hyperbilirubinemia, neonatal jaundice, phototherapy, treatment methods

\section{INTRODUCTION}

Bilirubin is a naturally occurring organic substance synthesized both in animals and some plants $[1,2]$. In the animal body it is produced as a bile pigment through a natural hemolytic process.

*Corresponding author. Tel.: +923006373150. E-mail: haqnawaz@bzu.edu.pk 
Bilirubin is synthesized in the reticuloendothelial cells of the spleen and the Kuffer cells of the liver by routine catabolic degradation of hemoglobin and other hemoproteins including myoglobin, cytochromes, catalase, and peroxidase pyrrolase. Hemoglobin is oxidized to hem that is further degraded to iron and porphyrin IXa and porphyrin IX to biliverdin by hem oxygenase. The green coloured biliverdin is then reduced to yellow coloured bilirubin by biliverdin reductase [3-5] (Fig. 1). The bilirubin molecule thus formed consists of a tetrapyrrol structure with two propionic acid side chains; it remains water-insoluble in free form due to the formation of six intramolecular hydrogen bonds, gets associated with serum albumin and is transported to the liver. In hepatocytes, it undergoes the process of conjugation with glucuronic acid (Fig. 2). The conjugated bilirubin is soluble in water and is excreted through bile into the small intestine and finally in feces [1,5-7]. The normal route of synthesis, transportation, conjugation and excretion of bilirubin is summarized in Fig. 1.

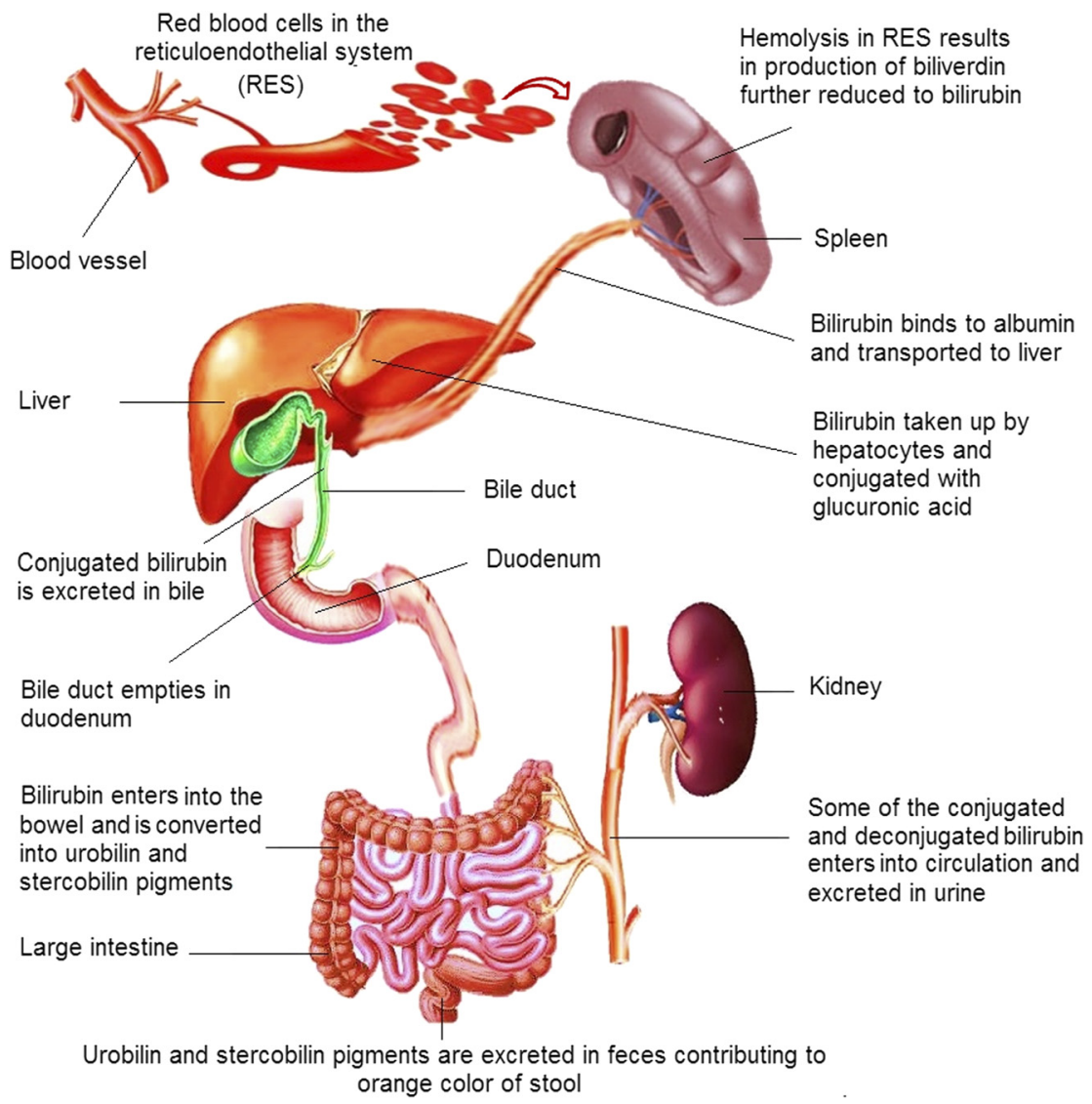

Fig. 1. Illustrations of the normal route of bilirubin metabolism 


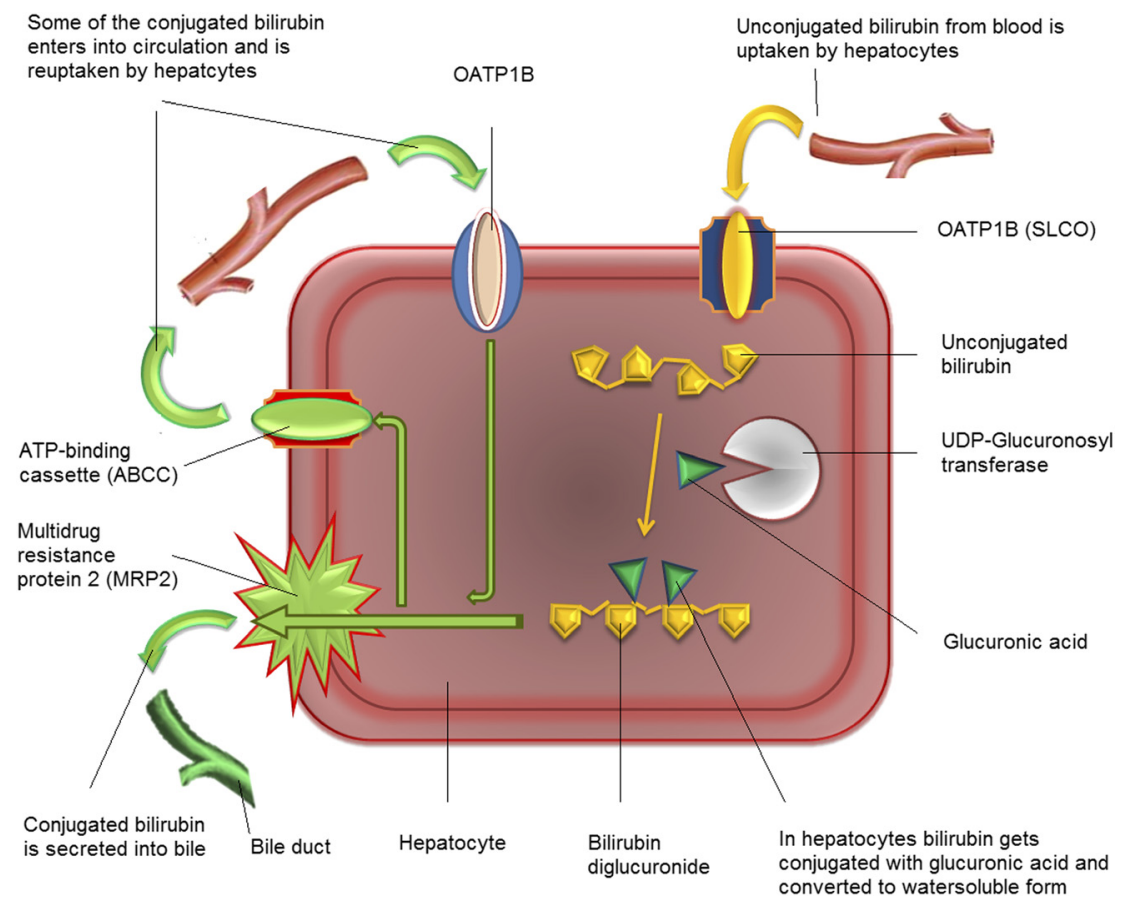

Fig. 2. Mechanism of synthesis and conjugation of bilirubin

\section{BILIRUBIN CONJUGATION AND EXCRETION}

At the blood-hepatocyte interface of the sinusoidal membrane, unconjugated bilirubin is dissociated from albumin and taken up by hepatocytes by facilitated diffusion through organic anion transporter polypeptides OATP1B1 and OATP1B3 [8, 9]. In hepatocytes, bilirubin binds to glutathione-S-transferase (GST), also known as ligandin, followed by conjugation with glucuronic acid catalyzed by the microsomal bilirubin uridine diphosphate glucuronosyl transferase (UGT) [10,11]. Glucuronic acid, due to its low affinity towards UGT, is first converted to uridine diphosphate glucuronic acid (UDPGA) catalyzed by glucose-6-phosphate dehydrogenase (G6PD), then conjugated with the propionic acid residues of bilirubin resulting in the breakdown of the intramolecular hydrogen bonds and formation of the hydrophilic bilirubin glucuronides. The water-soluble bilirubin diglucuronides are then transported to bile canaliculi by ATP-coupled transporters such as the multidrug resistance protein 2 (MRP2) and ATPbinding cassette $\mathrm{C} 2$ (ABCC2). A portion of conjugated bilirubin enters into sinusoidal blood via an $\mathrm{ABCC} 3$, re-up taken by sinusoidal OATP1B1 and OATP1B3 along with unconjugated bilirubin and excreted again into bile via MRP2 [12].

Once in the canaliculi, more than $98 \%$ of the total canalicular bilirubin is transported via the bile duct to the small intestine, where the canalicular unconjugated and deconjugated bilirubin (bilirubin glucuronides metabolized back to free bilirubin) is reabsorbed into the enterohepatic 
circulation through the intestinal epithelium via $\mathrm{ABCC} 3$, binds to albumin and is reuptaken by hepatic OATP. The reabsorption of conjugated bilirubin is not favored due to its hydrophilic nature. Conjugated bilirubin is excreted directly in feces along with other breakdown products and undigested food. However, unconjugated bilirubin is first reduced to urobilinogen and stercobilinogen by the intestinal microflora and then oxidized to urobilin and stercobilin pigment, respectively, for their excretion in feces which contribute to the color of stools. The concentration of urobilinogen may be increased in case of overproduction of bilirubin, reduced bilirubin clearance by hepatocytes and excessive exposure of bilirubin to intestinal bacteria $[5,7]$. The hepatocellular uptake, the process of conjugation, formation of bilirubin glucuronide, and canalicular excretion of bilirubin are summarized in Fig. 3.
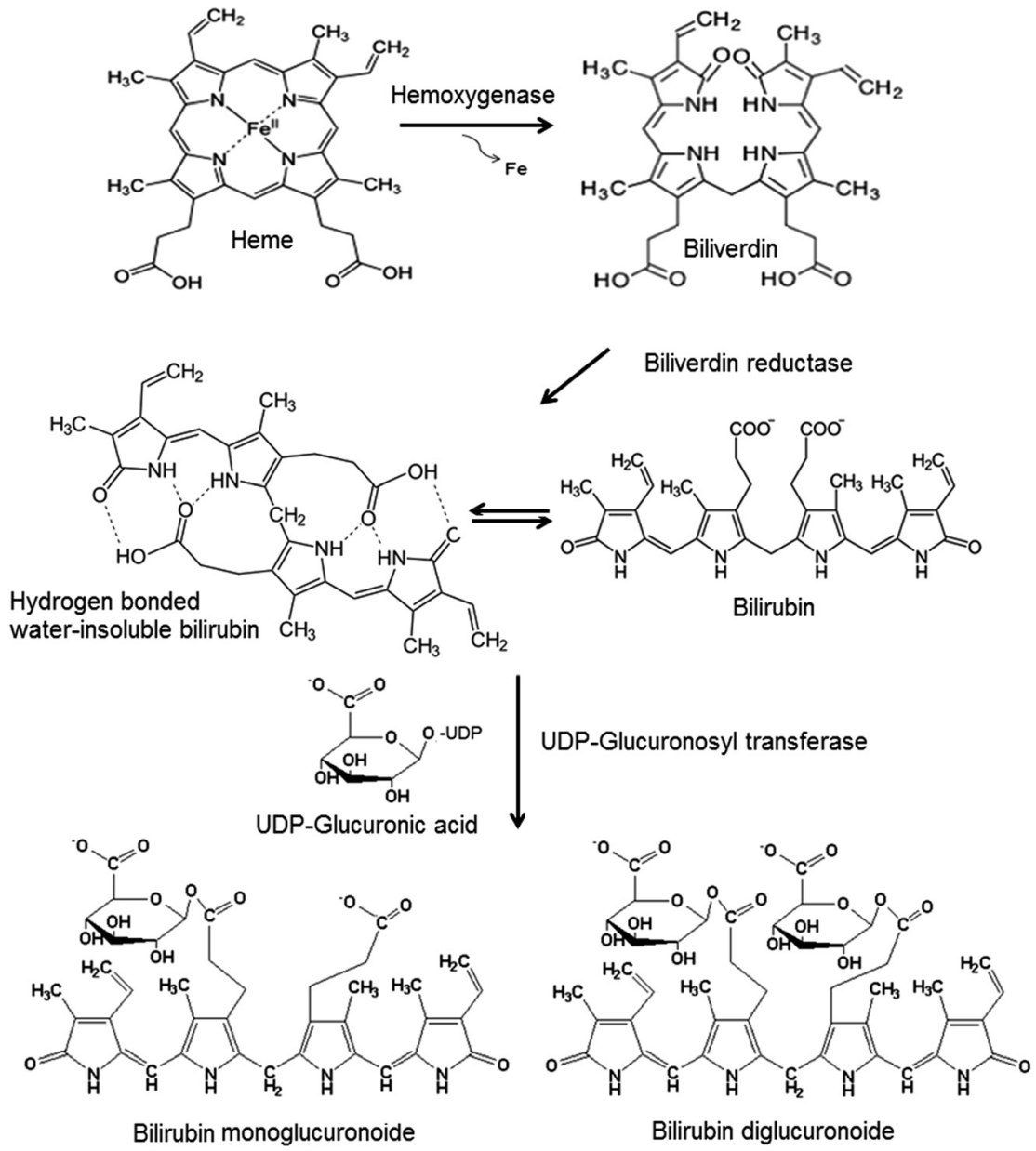

Fig. 3. Illustrations of hepatocellular uptake, conjugation and excretion of bilirubin 


\section{Hyperbilirubinemia and jaundice}

Excess hemolysis, abnormal hepatic uptake of unconjugated bilirubin, abnormalities in conjugation process in the case of immature liver, hepatitis, liver cirrhosis and obstruction in the biliary excretion of conjugated bilirubin are some of the factors responsible for an increase in serum bilirubin level, a clinical condition known as hyperbilirubinemia. Being insoluble in water, the unconjugated bilirubin gets deposited in adipose tissues resulting in yellow pigmentation of skin and eyes, a physiological condition known as jaundice $[7,13,14]$.

Depending on the factors responsible for hyperbilirubinemia, jaundice is categorized into pre-hepatic, hepatic, and post-hepatic jaundice. Pre-hepatic jaundice, also called hemolytic jaundice is associated with unconjugated hyperbilirubinemia mostly caused by excess hemolysis and overproduction of bilirubin beyond the conjugating capacity of the liver due to hyperactivity of hemoxygenase and biliverdin reductase, impaired albumin-bilirubin binding and defects in the hepatocellular uptake of bilirubin. Hepatic jaundice is associated with both conjugated and unconjugated hyperbilirubinemia caused by inappropriate conjugation of bilirubin with glucuronic acid due to low activity of UGT and impaired excretion of conjugated bilirubin into bile canaliculi [6, 7, 13, 15]. Post-hepatic jaundice, also known as obstructive jaundice, cholestatic jaundice or simply cholestasis, is associated with conjugated hyperbilirubinemia. The major factor responsible for post-hepatic jaundice is the impaired excretion of conjugated bilirubin due to defects in OATP and MRP2 or the obstruction of the bile duct [10].

\section{Neonatal Hyperbilirubinemia}

The elevated levels of serum bilirubin in neonates is clinically known as neonatal hyperbilirubinemia. The high rate of catabolic degradation of heme in fetal erythrocytes, defective heme oxygenase, defective biliverdin reductase, defective hepatocellular uptake due to polymorphism in OAPT1B, relatively low activity of UGT and impaired conjugation of bilirubin due to immature liver and defective G6PD result in unconjugated hyperbilirubinemia in neonates $[11,16-18]$. In neonates, UGT remains inactive during the foetal life and requires several days after birth for its induction up to functional levels. UGT activity is sometimes decreased due to the presence of UGT inhibitors such as pregnanediol, sterols, glucuronidase, non-esterified fatty acids, and some epidermal growth factors present in the breast milk of the mother resulting in unconjugated hyperbilirubinemia also known as breast milk jaundice. However, breast milk jaundice is not limited to UGT inhibitors but may also be associated with some genetic variation in the UGT1A1 gene [11]. Polymorphism in UGT1A1 has been found to be significantly associated with the risk of neonatal hyperbilirubinemia in different populations. The variation in $\mathrm{A}(\mathrm{TA})_{6} \mathrm{TAA}>\mathrm{A}(\mathrm{TA})_{7} \mathrm{TAA}$ at nucleotide -53 in the UGT1A1 gene plays a significant role in the development of neonatal hyperbilirubinemia in Caucasians and some Asian populations, such as Indians [19] and Malaysians [20]. However, in East-Asian populations, such as Chinese, Japanese and Taiwanese, 211 AA genotype is the main cause of neonatal hyperbilirubinemia, whereas $-53 \mathrm{~A}(\mathrm{TA})_{7} \mathrm{TAA} / \mathrm{A}(\mathrm{TA})_{7} \mathrm{~T}$ AA seems to have a protective effect against hyperbilirubinemia development in neonates fed with breast milk [21]. Breast milk jaundice can be differentiated from breast feeding jaundice that is characterized by decreased fluid intake and increased entero-hepatic recirculation of unconjugated and deconjugated bilirubin in breast-fed babies during the early days of life [22]. 
Neonatal cholestasis or cholestatic jaundice is associated with prolonged conjugated hyperbilirubinemia caused by the abnormalities, infections, and obstruction of the extrahepatic bile duct. Some antibacterial and antiviral drugs such as fusidic acid, salvianolic acid, Octreotide, Atazanavir and Indinavir have also been reported to inhibit the hepatocellular catalytic and transport system and contribute to drug-induced unconjugated and conjugated hyperbilirubinemia [23-26].

Hyperbilirubinemia is also characterized by genetic abnormalities in the genes associated with bilirubin metabolism (Fig. 4). Hyperbilirubinemia associated with UGT activity is linked to genetic polymorphism in the UGT1A1 gene coding for UGT. Unconjugated and conjugated hyperbilirubinemia may also be linked to the SLCO1B1 and SLCO1B3 genes coding for solute carrier organic anion (SLCO) transporter proteins OAPT1B1 and OAPT1B3, respectively. The reduced activity of these transporter proteins results in elevated levels of conjugated as well as unconjugated bilirubin in the serum. Polymorphism in the genes coding for the transporter protein MRP2 involved in the excretion of conjugated bilirubin is also associated with unconjugated and conjugated hyperbilirubinemia [27]. The genetic disorders of bilirubin conjugation and excretion responsible for hyperbilirubinemia include Gilbert's Syndrome (GS), Crigler Najjar Syndrome (CNS), Rotor's Syndrome (RS) and Dubin-Johnson's Syndrome (DJS). GS and CNS are inherited disorders generally characterized by inherited unconjugated hyperbilirubinemia associated with decreased conjugation of bilirubin in hepatocytes due to defective expression of the UGT gene $[10,11,28]$. RS is a rare disorder characterized by low grade conjugated hyperbilirubinemia due to defective reuptake of conjugated bilirubin by sinusoidal

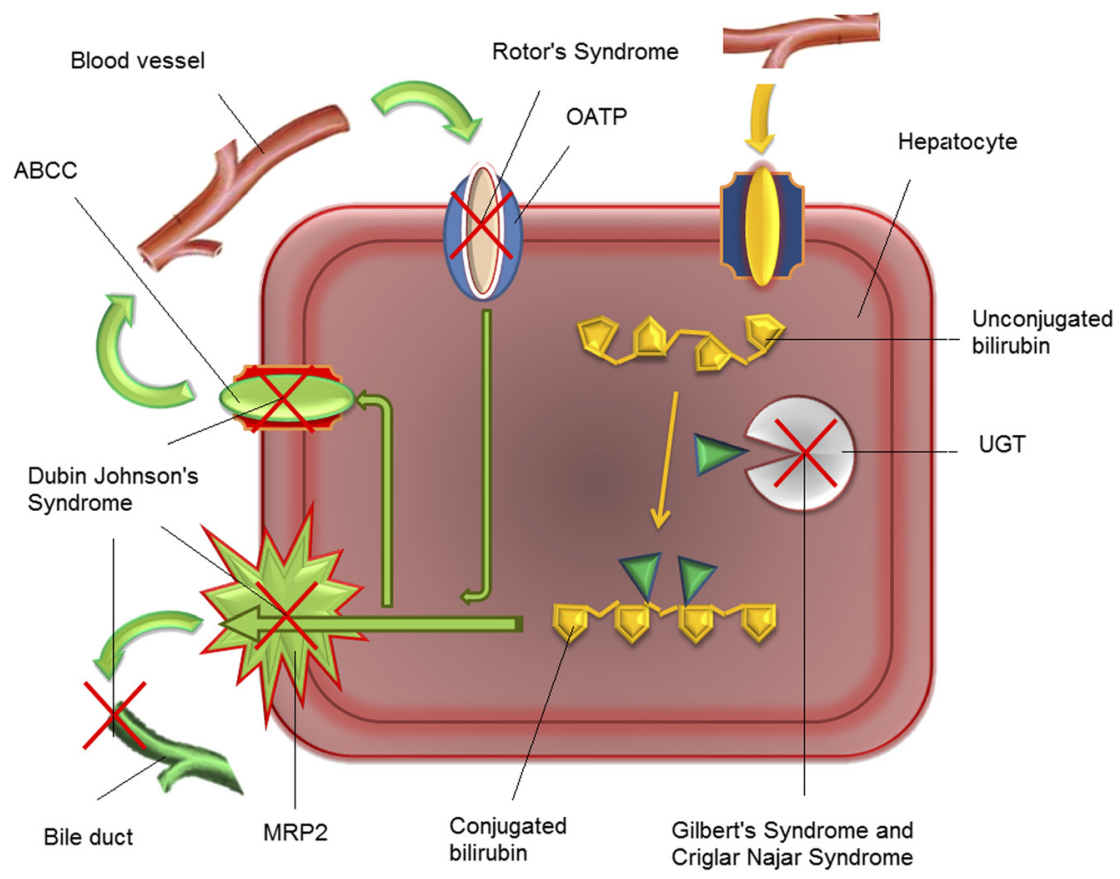

Fig. 4. Illustrations of the disorders of bilirubin uptake, conjugation and excretion 
transporters OATP1B1 and OATP1B3 [17]. The genetics behind DJS is an autosomal recessive disorder characterized by inherited conjugated hyperbilirubinemia due to defects in the canalicular excretion of conjugated bilirubin by ATP-dependent canalicular transport pumps ABCC1, ABCC2, ABCC3, and MRP2 [11, 12, 17].

\section{CHEMICAL METHODS FOR DETERMINATION OF BILIRUBIN AND DIAGNOSIS OF HYPERBILIRUBINEMIA}

\section{Diazo method}

In circulation, bilirubin is normally found as unconjugated (indirect) bilirubin and conjugated (direct) bilirubin. Clinically bilirubin is measured as total serum bilirubin and serum direct bilirubin by a modified diazo method based on Van Den Bergh's reaction [29]. This method is based on the formation of the diazo-bilirubin complex by the reaction of bilirubin in the sample with diazonium ion (formed by the reaction of sulphanilic acid and sodium nitrite) in an alkaline medium.

$$
\begin{aligned}
& \text { sulphanilic acid }+ \text { sodium nitrite } \rightarrow \text { diazonium ion } \\
& \text { bilirubin }+ \text { diazonium ion } \rightarrow \text { azo }- \text { bilirubin }(\text { colored complex })
\end{aligned}
$$

The green-colored diazo-bilirubin complex has its absorption maximum at 540-560 nm and can be measured spectrophotometrically. For the determination of serum total bilirubin, caffeine is added to release the albumin-bound unconjugated bilirubin. The test performed without the addition of caffeine measures conjugated bilirubin only. The concentration of unconjugated or indirect bilirubin in the serum can be calculated by the difference between total and direct bilirubin.

Although this is a quick, accurate and widely used clinical method for the diagnosis of jaundice and hyperbilirubinemia, yet it has some limitations in the field of research. This method determines the concentration of total and direct bilirubin but not that of the bilirubin conjugates and its degradation products. It is therefore necessary to find new methods not limited to bilirubin concentration only but also suitable for the identification and simultaneous determination of bilirubin conjugates and their degradation products in body fluids.

\section{Peroxidase method}

It is an enzymatic method for the determination of free bilirubin but not albumin-bound bilirubin. The method is based on the principle that horseradish peroxidase catalyzes rapid oxidation of unbound free bilirubin, whereas albumin-bound bilirubin remains protected $[5,30]$. The method is effective and validated for the determination of unbound free bilirubin in the serum both in conjugated and unconjugated form and can also be used to determine the binding affinity of bilirubin to albumin [31]. However, this method is limited to free bilirubin and it does not measure the degradation products of bilirubin.

\section{Bilirubin oxidase method}

This is an enzymatic method used for the determination of total serum bilirubin and direct bilirubin. The method is based on the enzymatic oxidation of bilirubin to biliverdin catalyzed by 
bilirubin oxidase obtained from Myrothecium verrucaria [32, 33]. In the first step, bilirubin is oxidized to biliverdin and in the subsequent step biliverdin thus formed is further oxidized to a purple-colored complex which can be measured spectrophotometrically or amperometrically using oxygen electrodes [34]. The method is equally effective for the determination of total bilirubin and direct bilirubin as both are oxidized at the same $\mathrm{pH}$ (7.2 and 7.3 respectively). High performance liquid chromatographic analysis before and after the enzymatic oxidation of bilirubin has shown that the method is highly specific with no significant interference by reducing substances, hemoglobin, and anticoagulants.

\section{Light absorption method}

In previous decades researchers have used the light absorption method for the determination of bilirubin in diluted serum. In normal sera, more than $90 \%$ of the yellow color is contributed by bilirubin, whereas the residual $10 \%$ is due to the presence of other substances including carotenes. In hyperbilirubinemic sera, the color of bilirubin dominates the others in the reading. Bilirubin in serum has its absorption maximum at $453 \mathrm{~nm}$, which can be used for the spectrophotometric determination of bilirubin in serum. However, the measurement is impeded by various interfering factors, mainly oxyhemoglobin, which also has maximal absorption at the same wavelength. The presence of albumin in the serum is another interfering factor which has been found to alter the absorption maximum of bilirubin [35].

\section{Non-invasive method}

To avoid the pain and other complications of blood sampling, some non-invasive methods have also been developed for the determination of bilirubin in jaundiced neonates. Transcutaneous bilinometer, the handheld fiber optic sensing device has been designed for the detection and measurement of jaundice. The meter first illuminates the skin and subcutaneous tissues and then measures the intensity of the yellow color of bilirubin spectrophotometrically. The method is accurate with a significant correlation of results with those obtained by the diazo method [36]. Although the method is quick, economical and easy to handle, yet it is limited to the determination of total bilirubin level in the skin. Another non-invasive method for determination of bilirubin is pulse oximetry. This method is based on the principle that the bilirubin in blood running in the pulse absorbs light at a wavelength different from that absorbed by hemoglobin. The pulse oximeter determines bilirubin similarly to a bilinometer using light around $480 \mathrm{~nm}$. However, the results obtained with a transcutaneous bilinometer lose their correlation with the invasive methods at a level of approximately $10 \mathrm{mg} / \mathrm{dL}$ [37].

\section{High-performance liquid chromatography (HPLC)}

HPLC is an advanced method used for the identification and determination of bilirubin, its conjugates and degradation products $[38,39]$. It is an advanced and reliable method that has been proved to be useful for studying the metabolic and degradation products of bilirubin including bilirubin glucuronides, its photo isomers, as well as products of the radiolysis and intestinal oxidation of bilirubin $[40,41]$. Compared to other methods reported and used for the determination of serum bilirubin, HPLC is the best method as it gives better separation and quantification of the components of a mixture. It is more accurate, precise, highly specific and reliable than the diazo, the direct spectrophotometric and the subcutaneous bilinometric 
methods [42]. Compared to direct spectrophotometry, HPLC is insensitive to interference by other pigments found in the serum [43]. The individual fractions of various derivatives of bilirubin produced by metabolic, photolytic and radiolysis treatments can be measured accurately by the use of an internal standard and calibration of the method with standard bilirubin solution.

\section{Currently used methods of treatment of hyperbilirubinemia}

Hyperbilirubinemia is known to cause bilirubin-induced neurological disfunction (BIND) such as acute encephalopathy in the first few weeks of life, sometimes kernicterus spectrum disorder (KSD) beyond the neonate with a range of problems including deafness, choreoathetoid cerebral palsy, and language processing disorder $[44,45]$. A high bilirubin/albumin ratio or abnormal bilirubin-albumin binding due to interference of some drugs leads to cerebral toxicity in neonates. Prolonged hyperbilirubinemia causes irreversible BIND that may lead to death in neonates $[46,47]$. An immediate and thorough clearance of bilirubin from the body is necessary by conversion of the water-insoluble compound to the water-soluble one. Several methods have been developed to convert hydrophobic unconjugated bilirubin to excretable products for the management of hyperbilirubinemia.

\section{Phototherapy}

Phototherapy involving photo-degradation of bilirubin by white or blue light is the most commonly used method for the treatment of hyperbilirubinemia. Phototherapy is based on the photo-oxidation of hydrogen-bonded bilirubin with $\mathrm{ZZ}$ conformation, resulting in the breakdown of intramolecular hydrogen bonds and formation of bilirubin photo-isomers with EZ or ZE conformation. These photo-isomers, being water-soluble, are excreted easily from the body. However, this treatment method has certain limitations. The time needed under phototherapy is variable depending on many factors including irradiance of the phototherapy unit, etiology of the hyperbilirubinemia and exposure of the neonate but can be prolonged in some cases, and must be discontinued during feeding. There is also a chance of rebinding of bilirubin after phototherapy and dehydration due to sweating [48, 49].

\section{Chemical treatment}

Phenobarbital and phenobarbitone treatment have been proved to be helpful in the management of unconjugated hyperbilirubinemia caused by the reduced activity of UGT in neonates. Phenobarbital has been found to induce UGT activity by increasing the expression of the UGT1A1 gene [50]. However, this treatment takes several days to induce UGT and, therefore, it is not preferable for the immediate clearance of significant hyperbilirubinemia. This treatment method is also limited to UGT-dependent unconjugated hyperbilirubinemia and cannot be used for conjugated hyperbilirubinemia [7]. The oral administration of bilirubin oxidase, an enzyme that oxidizes bilirubin into less toxic water-soluble products uses its immobilized form to reduce the toxic effects of bilirubin in the intestines [51]. Oral administration of charcoal and agar prevents hyperbilirubinemia due to enterohepatic circulation of canalicular unconjugated bilirubin and deconjugated bilirubin [7]. However, this treatment is also limited to UGT-dependent unconjugated hyperbilirubinemia and cannot be used for conjugated hyperbilirubinemia. 


\section{Herbal treatment}

Herbal treatment has been a favorable and effective traditional method for the management of hyperbilirubinemia. A variety of herbs are effective in the treatment of certain liver diseases including hepatitis and jaundice. Cichorium incubus L., commonly known as chicory is a traditionally used medicinal plant that possesses several medicinal properties such as antioxidant, anti-inflammatory, anti-ulcerogenic, anti-cancer, anti-bacterial and anti-hepatotoxic activities. All parts of this plant have been used traditionally for the treatment of jaundice and gallstones [52]. Annona muricata (Linn.) is another medicinal plant traditionally used for the treatment of jaundice. This has been reported to possess hepatoprotective properties. It is effective in the treatment of carbon tetrachloride- and acetaminophen-induced jaundice in rats [53]. Agaricus brasiliensis has also been found to be effective in the treatment of phenylhydrazine $(\mathrm{PH})$ induced neonatal jaundice in rats [54]. There are several other medicinal plants including Prunus domestica, Equisetum debile, Phyllanthus emblica, Punica granatum, and Raphnus sativus, commonly used for the treatment of jaundice by practitioners [55]. Although herbal treatment has very few side effects, still it has a slow recovery rate and is not a favorable method for the treatment of neonatal jaundice.

\section{Exhange transfusion}

Blood transfusion or plasmapheresis is another method for the treatment of hyperbilirubinemia. In exchange transfusion, the infant's blood is removed in aliquots $(15-20 \mathrm{~mL})$ and replaced by reconstituted blood (one unit of $\mathrm{O}$ negative packed red blood cells reconstituted with one unit of $\mathrm{AB}$ fresh frozen plasma to avoid the issues of $\mathrm{ABO}$ or Rh incompatibility). Exchange transfusion results in acute lowering of the infant's bilirubin level as well as immature red blood cells to avoid early hemolysis due to transplacental passage of maternal antibodies. Due to adverse effects of exchange transfusion including thrombocytopenia, hypokalemia, metabolic acidosis, and seizures as well as to improvements in phototherapy and other treatment methods, this method is not used commonly for treatment of hyperbilirubinemia. However, this treatment may be preferred in case if phototherapy fails to significantly reduce the infant's bilirubin level [56-58].

Plasmapheresis is used for the detoxification of blood by the removal of bilirubin and other toxic substances. In plasmapheresis, the blood is removed from the hyperbilirubinemic patient and blood cells are separated from plasma followed by the replacement of plasma with bilirubinfree human plasma from another source. The blood containing normal bilirubin level is transfused back into the patient [59-61]. Although this method is useful in the treatment of hyperbilirubinemia, yet it has chances of contamination and infections.

\section{Liver transplant}

Liver transplant has been an option for the treatment of jaundice particularly in inherited disorders of bilirubin metabolism including CNS and GS, hepatitis and liver carcinoma when all other remedies are ineffective. A successful transplant of the liver has been reported in two brothers with CNS-II [62]. The progress and innovations in the method and protocols for the transplantation of hepatocytes in jaundiced patients have also been reviewed and reported in the subsequent literature [63]. However, the use of the liver transplantation method is limited due to its cost, immunological problems, and unavailability of donors. 


\section{Gene replacement therapy}

Recently a new method for the treatment of jaundice caused by a genetic disorder in bilirubin metabolism has been introduced. This treatment method is based on the replacement of genes responsible for the expression of the proteins involved in bilirubin metabolism. It has been suggested that the Rotor's syndrome and Crigler-Najjar's syndrome may be treated by the replacement of genes involved in the expression of OATP and UGT $[64,65]$.

\section{Recent advancements in the treatment of hyperbilirubinemia}

Researchers have recently modified the methods previously used for the treatment and management of hyperbilirubinemia in neonates. Table 1 presents the findings of some of the latest studies regarding the new methods of treatment of hyperbilirubinemia and jaundice reported in the last decade (2011-2020). Phototherapy has been the most effective and commonly used method for the management of hyperbilirubinemia. However, recent studies have shown that the use of filtered sunlight, white reflecting curtains, broad-spectrum light, double-sided LED machines, portable LED phototherapy device and LED light mesh (sleeping bag and blanket) is more effective in reduction of hyperbilirubinemia in neonates compared to conventional phototherapy $[66,67]$.

Immunoglobulin therapy has also been an effective method used for increasing the clearance of bilirubin and minimizing the duration of phototherapy and the need of exchange transfusion in hemolytic jaundice in ABO-incompatible and Rh-positive neonates [68-70]. However, an intravenous administration of immunoglobulin (IVIG) during phototherapy by light emitting diodes (LED) showed no significant dose-dependent increase in bilirubin clearance in ABOincompatible neonates [71].

Porphyrin therapy has been used for 3-4 decades as a tool for the management of hyperbilirubinemia by inhibiting hemoxygenase [72]. However, supplementation of Zn-protoporphyrin during phototherapy significantly inhibited hemoxygenase in newborn mouse model. The Zn-protoporphyrin-lipid treatment has also been found to be effective in inhibition of hemoxygenase and reduction of hyperbilirubinemia in newborn mouse models [73]. The combination of phototherapy and SnMP also effectively reduced the duration and need of repeated phototherapy for the treatment of hyperbilirubinemia in infants with hemolytic disease due to $\mathrm{Rh}$ incompatibility [74].

A combination of a single dose $(50 \mathrm{mg} / \mathrm{kg})$ of clofibrate and phototherapy also significantly reduced the duration of phototherapy and hospital stay of healthy term hyperbilirubinemic neonates [75]. Supplementation of a suspension of fenofibrate and vitamin D, E, and C during white light therapy significantly reduced bilirubin levels and the duration of phototherapy in neonates [76]. The administration of oxaliplatin in combination with fluro-pyrimidine/folinic acid and monoclonal antibody, and supplementation of zinc sulfate syrup and Yinzhihuang oral liquid during phototherapy are also effective for reduction of bilirubin in neonates [77-79].

As discussed earlier, herbal therapy has been a traditionally used method for the treatment of jaundice. Recently, the combination of herbal therapy with phototherapy has been found to be more effective than either method used individually. Administration of a $3.75 \mathrm{mg} / \mathrm{kg}$ dose of silymarin (a herbal compound) twice a day effectively reduced the duration of phototherapy for the management of unconjugated hyperbilirubinemia in neonates [80]. Hand massage and the combination of traditional Chinese medicine with massage has also been found an effective option for bilirubin clearance [81, 82]. 
Table 1. Recent advancement in the treatment of hyperbilirubinemia and jaundice

\begin{tabular}{|c|c|c|c|c|c|}
\hline $\begin{array}{l}\text { Year of } \\
\text { study }\end{array}$ & Treatment method & $\begin{array}{l}\text { Subject/Experimental } \\
\text { model }\end{array}$ & $\begin{array}{c}\text { Treatment source/ } \\
\text { material }\end{array}$ & Conclusive findings & Reference \\
\hline 2011 & $\begin{array}{l}\text { Chemical treatment } \\
\text { with phototherapy }\end{array}$ & $\begin{array}{c}\text { Neonates with } \mathrm{ABO} \\
\text { incompatibility }\end{array}$ & $\begin{array}{l}\text { Immunoglobulin } \\
\text { (IVIG) with LED }\end{array}$ & $\begin{array}{l}\text { The supplementation of IVIG with LED has no } \\
\text { significant dose-dependent effect on the need for } \\
\text { exchange transfusion and erythrocyte transfusion } \\
\text { and on the duration of hospitalization for the } \\
\text { treatment of hemolytic disease in neonates. }\end{array}$ & [71] \\
\hline 2012 & $\begin{array}{l}\text { Chemical treatment } \\
\text { with phototherapy }\end{array}$ & Neonates & $\begin{array}{l}\text { Clofibrate (single dose } \\
50 \mathrm{mg} / \mathrm{kg} \text { ) and blue } \\
\text { light }\end{array}$ & $\begin{array}{l}\text { A single dose of clofibrate }(50 \mathrm{mg} / \mathrm{kg}) \text { effectively } \\
\text { reduced the duration of phototherapy and } \\
\text { hospital stay of healthy term hyperbilirubinemic } \\
\text { neonates. }\end{array}$ & [75] \\
\hline 2012 & $\begin{array}{l}\text { Chemical treatment } \\
\text { with phototherapy }\end{array}$ & $\begin{array}{l}\text { Infants with Rh } \\
\text { incompatibility }\end{array}$ & $\begin{array}{l}\text { Sn-mesoporpyrins } \\
\text { (SnMP) and blue } \\
\text { fluorescent light }\end{array}$ & $\begin{array}{l}\text { SnMP supplementation effectively prevented the } \\
\text { need for repeated phototherapy for the treatment } \\
\text { of hyperbilirubinemia in infants with hemolytic } \\
\text { disease due to Rh incompatibility. }\end{array}$ & {$[74]$} \\
\hline 2012 & Gene therapy & $\begin{array}{l}\text { Transgenic mice } \\
\text { deficient in organic } \\
\text { anion transporter } \\
\text { protein (OATP) }\end{array}$ & $\begin{array}{l}\text { Human OATP1A1 or } \\
\text { OATP1B1 gene }\end{array}$ & $\begin{array}{l}\text { The transgenic insertion and expression of } \\
\text { human The OATP1A1 or OATP1B1 gene } \\
\text { enhanced bilirubin clearance and prevented the } \\
\text { onset of Rotor's Syndrome. }\end{array}$ & [9] \\
\hline 2013 & $\begin{array}{c}\text { Herbal treatment with } \\
\text { phototherapy }\end{array}$ & Neonates & $\begin{array}{l}\text { Silymarin and white } \\
\text { fluorescent light }\end{array}$ & $\begin{array}{l}\text { Administration of } 3.75 \mathrm{mg} / \mathrm{kg} \text { dose of silymarin } \\
\text { twice a day effectively reduced bilirubin levels } \\
\text { and duration of phototherapy for the } \\
\text { management of unconjugated hyperbilirubinemia } \\
\text { in neonates. }\end{array}$ & {$[80]$} \\
\hline 2013 & Phototherapy & Infants & Filtered sunlight & $\begin{array}{l}\text { Filtered sunlight was found to be safe and } \\
\text { efficacious over conventional phototherapy and } \\
\text { exchange transfusion for the management of } \\
\text { hyperbilirubinemia in poorly resourced countries } \\
\text { like Nigeria. }\end{array}$ & [83] \\
\hline
\end{tabular}


Table 1. Continued

\begin{tabular}{|c|c|c|c|c|c|}
\hline $\begin{array}{l}\text { Year of } \\
\text { study }\end{array}$ & Treatment method & $\begin{array}{l}\text { Subject/Experimental } \\
\text { model }\end{array}$ & $\begin{array}{c}\text { Treatment source/ } \\
\text { material }\end{array}$ & Conclusive findings & Reference \\
\hline 2015 & Phototherapy & Neonates & $\begin{array}{c}\text { White reflecting } \\
\text { curtains }\end{array}$ & $\begin{array}{c}\text { The use of white reflecting curtains was found to } \\
\text { be more effective than conventional phototherapy } \\
\text { in the reduction of bilirubin levels due to high } \\
\text { spectral irradiance and exposure of large surface } \\
\text { area. }\end{array}$ & [84] \\
\hline 2015 & Phototherapy & Neonates & $\begin{array}{l}\text { Broad-spectrum light } \\
\text { (BSL) versus blue } \\
\text { LEDs }\end{array}$ & $\begin{array}{l}\text { Phototherapy with BSL reduced the duration of } \\
\text { treatment compared to that with LED for the } \\
\text { management of hyperbilirubinemia in late } \\
\text { preterm and term infants. }\end{array}$ & [85] \\
\hline 2016 & Chemical treatment & $\begin{array}{c}\text { Newborn mouse } \\
\text { model }\end{array}$ & $\begin{array}{l}\text { Zn-protoporphyrin- } \\
\text { lipid (ZnPP-lipid) }\end{array}$ & $\begin{array}{l}\text { The ZnPP-lipid treatment effectively inhibited } \\
\text { liver HO and can be used for the treatment of } \\
\text { hyperbilirubinemia in hemolytic disease. }\end{array}$ & [73] \\
\hline 2016 & Chemical treatment & $\begin{array}{l}\text { Patients with } \\
\text { hyperbilirubinemia } \\
\text { secondary to liver } \\
\text { metastases of } \\
\text { gastrointestinal cancer }\end{array}$ & $\begin{array}{l}\text { Oxaliplatin with fluro- } \\
\text { pyrimidine/folinic } \\
\text { acid } \pm \text { monoclonal } \\
\text { antibody }\end{array}$ & $\begin{array}{l}\text { Treatment with oxaliplatin, FP/FA with and } \\
\text { without monoclonal antibody effectively dropped } \\
\text { the bilirubin level and can be beneficial for the } \\
\text { management of hyperbilirubinemia in patients } \\
\text { with liver dysfunction. }\end{array}$ & [77] \\
\hline 2017 & Chemical treatment & Neonates & $\begin{array}{l}\text { Yinzhihuang oral } \\
\text { liquid }\end{array}$ & $\begin{array}{l}\text { Treatment with Yinzhihuang oral liquid } \\
\text { significantly eliminated the overproduced } \\
\text { bilirubin and may be used as an effective } \\
\text { treatment option for neonatal jaundice. }\end{array}$ & [86] \\
\hline 2018 & Phototherapy & Infants & $\begin{array}{c}\text { Double-sided LED } \\
\text { machine }\end{array}$ & $\begin{array}{l}\text { The use of a double-sided phototherapy machine } \\
\text { enhanced the rate of clearance of serum bilirubin } \\
\text { and decreased the duration of phototherapy and } \\
\text { stay at the hospital. }\end{array}$ & [66] \\
\hline
\end{tabular}


Table 1. Continued

\begin{tabular}{lccc}
\hline $\begin{array}{l}\text { Year of } \\
\text { study }\end{array}$ & Treatment method & $\begin{array}{c}\text { Subject/Experimental } \\
\text { model }\end{array}$ & $\begin{array}{c}\text { Treatment source/ } \\
\text { material }\end{array}$ \\
\hline 2018 & $\begin{array}{c}\text { Chemical treatment } \\
\text { with phototherapy }\end{array}$ & Neonates & $\begin{array}{c}\text { Zinc sulfate and blue } \\
\text { LED lamps }\end{array}$
\end{tabular}

2018 Exchange transfusion Neonates

Phototherapy

Neonates

Filtered sunlight versus electric light

Massage

Infants
Neonates with massage medicine washing combined with massage

Conclusive findings

Despite the inhibition of enterohepatic circulation of bilirubin, the zinc salt showed no significant effect on bilirubin clearance and might not be effective in the treatment of physiological jaundice in neonates.

Exchange transfusion initially decreased the bilirubin level that was intensified $6 \mathrm{~h}$ after the treatment. The increase in bilirubin levels after the treatment may be correlated with the prooxidant-antioxidant balance.

Filtered sunlight was found to be safe, efficacious, inexpensive, and did not interfere with conventual phototherapy in the treatment of neonatal jaundice. However, it did not work better than intensive electric phototherapy for the management of hyperbilirubinemia in neonates. Massage treatment is effective in lowering serum and cutaneous bilirubin levels and increasing defecation frequency in infants.

The combination of Chinese medicine washing and massage increases the excretion of meconium, reduces the duration of

Reference

transformation of meconium and decreases cutaneous and serum bilirubin. Therefore, it may be an effective option for the treatment of neonatal jaundice. 
Table 1. Continued

\begin{tabular}{|c|c|c|c|c|c|}
\hline $\begin{array}{l}\text { Year of } \\
\text { study }\end{array}$ & Treatment method & $\begin{array}{l}\text { Subject/Experimental } \\
\text { model }\end{array}$ & $\begin{array}{c}\text { Treatment source/ } \\
\text { material }\end{array}$ & Conclusive findings & Reference \\
\hline 2018 & $\begin{array}{l}\text { Chemical treatment } \\
\text { combined with } \\
\text { phototherapy }\end{array}$ & Neonates & $\begin{array}{l}\text { Yinzhihuang oral } \\
\text { liquid and blue light }\end{array}$ & $\begin{array}{l}\text { Treatment with Yinzhihuang oral liquid in } \\
\text { combination with phototherapy eliminated } \\
\text { bilirubin at a significantly higher rate than } \\
\text { phototherapy alone. This combination was } \\
\text { suggested to be safe and superior to phototherapy } \\
\text { alone for the treatment of neonatal jaundice. }\end{array}$ & [78] \\
\hline 2019 & Home phototherapy & Neonates & Blue light & $\begin{array}{l}\text { The home phototherapy method significantly } \\
\text { reduced hospital term admissions and was found } \\
\text { to be cost-effective and well-appreciated by } \\
\text { parents. }\end{array}$ & [90] \\
\hline 2020 & Chemical treatment & Neonates & Agar and blue light & $\begin{array}{l}\text { Oral supplementation of agar during } \\
\text { phototherapy effectively reduced bilirubin levels } \\
\text { and the duration of phototherapy, and was } \\
\text { suggested to be safe and effective for fast } \\
\text { management of neonatal hyperbilirubinemia. }\end{array}$ & [91] \\
\hline 2020 & $\begin{array}{l}\text { Chemical treatment } \\
\text { with phototherapy }\end{array}$ & Neonates & $\begin{array}{c}\text { Fenofibrate } \\
\text { suspension, vitamin } D \text {, } \\
\text { E and C, and white } \\
\text { lamps }(420-480 \mathrm{~nm})\end{array}$ & $\begin{array}{l}\text { The administration of a single dose of fenofibrate } \\
\text { and vitamin D significantly reduced the bilirubin } \\
\text { level, the duration of phototherapy and stay at } \\
\text { hospital. This treatment method was suggested to } \\
\text { be effective in the treatment of } \\
\text { hyperbilirubinemia in neonates receiving } \\
\text { phototherapy. }\end{array}$ & {$[76]$} \\
\hline 2020 & $\begin{array}{l}\text { Novel phototherapy } \\
\text { devices versus } \\
\text { conventional } \\
\text { phototherapy }\end{array}$ & Neonates & $\begin{array}{l}\text { LED light mesh } \\
\text { (sleeping bag and } \\
\text { blanket) }\end{array}$ & $\begin{array}{l}\text { The newly developed devices and conventional } \\
\text { phototherapy are equally effective in the } \\
\text { treatment of neonatal jaundice. However, these } \\
\text { devices are helpful in increasing the mother- } \\
\text { infant contact for bonding and breastfeeding. }\end{array}$ & [67] \\
\hline
\end{tabular}




\begin{tabular}{|c|c|c|c|c|c|}
\hline $\begin{array}{l}\text { Year of } \\
\text { study }\end{array}$ & Treatment method & $\begin{array}{l}\text { Subject/Experimental } \\
\text { model }\end{array}$ & $\begin{array}{c}\text { Treatment source/ } \\
\text { material }\end{array}$ & Conclusive findings & Reference \\
\hline 2020 & Double phototherapy & Infants & $\begin{array}{l}\text { White halogen lamps } \\
\text { or blue fluorescent } \\
\text { tubes }\end{array}$ & $\begin{array}{l}\text { Double phototherapy showed a high rate of } \\
\text { reduction of serum bilirubin level and was } \\
\text { suggested to be more effective than single } \\
\text { phototherapy in reducing serum bilirubin in } \\
\text { infants. }\end{array}$ & [92] \\
\hline 2020 & $\begin{array}{l}\text { Chemical treatment } \\
\text { with phototherapy }\end{array}$ & Neonates & $\begin{array}{c}\text { Zinc sulfate syrup and } \\
\text { blue light }\end{array}$ & $\begin{array}{l}\text { The use of zinc sulfate syrup significantly reduced } \\
\text { indirect hyperbilirubinemia in preterm neonates } \\
\text { within } 48 \mathrm{~h} \text {. }\end{array}$ & [79] \\
\hline 2020 & Chemical treatment & $\begin{array}{l}\text { Pregnant mother (last } \\
\text { month of pregnancy)/ } \\
\text { Neonates }\end{array}$ & Vitamin C & $\begin{array}{l}\text { Supplementation of vitamin } C \text { to mothers in the } \\
\text { last month of pregnancy significantly reduces } \\
\text { serum bilirubin and the risk of } \\
\text { hyperbilirubinemia in neonates. }\end{array}$ & [93] \\
\hline
\end{tabular}


Recently, a new method for the treatment of jaundice caused by a genetic disorder in bilirubin metabolism has been introduced. This treatment method is based on the replacement of genes responsible for the expression of the proteins involved in bilirubin metabolism. It has been suggested that Gilberts syndrome and Crigler-Najjar's syndrome may be treated by the replacement of genes involved in the expression of OATP and UGT [64, 65]. In a trial on mice the transgenic insertion and expression of human OATP1A1 or OATP1B1 enhanced bilirubin clearance and prevented the onset of Rotor's Syndrome [9]. However, this method of treatment is cost-ineffective and immunologically unsafe.

\section{Further suggestions}

Although several studies have been performed to find the best methods for the management of neonatal hyperbilirubinemia, the most convenient, quick, reliable, safe, and time- and costeffective method has still not been identified. It is also necessary to optimize the required time and dosage for significant clearance of bilirubin for each of the previously reported methods to obtain better results.

\section{REFERENCES}

1. Hansen TWR. Core concepts: Bilirubin metabolism. NeoReviews 2010; 11(6): e316-22.

2. Pirone CL. Bilirubin: an animal pigment in the zingiberales and diverse angiosperm orders. FIU Electronic Theses and Dissertations; 2010, vol. 336. https://doi.org/10.25148/etd.FI10122201.

3. Trivin F, Odievre M. Bilirubin metabolism in the newborn. Recent progress. Arch Fr Pediatr 1976; 33(3): 293-304.

4. Porter ML, Dennis MBL. Hyperbilirubinemia in the term newborn. Am Fam Physician 2002; 65(4): 599.

5. Bloomer JR, Risheg H. Bilirubin and porphyrin metabolism. In: Atlas of the liver. Springer; 2004, pp. 1-17.

6. Wang X, Chowdhury JR, Chowdhury NR. Bilirubin metabolism: Applied physiology. Curr Paediatr 2006; 16(1): $70-4$.

7. Roy-Chowdhury N, Lu Y, Roy-Chowdhury J. Bilirbuin metabolism. Textb Hepatol Basic Sci Clin Pract 2008; 165-74.

8. Lin Z, Fontaine J, Watchko JF. Coexpression of gene polymorphisms involved in bilirubin production and metabolism. Pediatrics 2008; 122(1): e156-62.

9. van de Steeg E, Stráneckỳ V, Hartmannová H, Nosková L, Hřebíček M, Wagenaar E, et al. Complete OATP1B1 and OATP1B3 deficiency causes human Rotor syndrome by interrupting conjugated bilirubin reuptake into the liver. J Clin Invest 2012; 122(2): 519-28.

10. Bosma PJ. Inherited disorders of bilirubin metabolism. J Hepatol 2003; 38(1): 107-17.

11. Memon N, Weinberger BI, Hegyi T, Aleksunes LM. Inherited disorders of bilirubin clearance. Pediatr Res 2016; 79(3): 378-86.

12. Bellarosa C, Bortolussi G, Tiribelli C. The role of ABC transporters in protecting cells from bilirubin toxicity. Curr Pharm Des 2009; 15(25): 2884-92.

13. Ullah S, Rahman K, Hedayati M. Hyperbilirubinemia in neonates: types, causes, clinical examinations, preventive measures and treatments: A narrative review article. Iran J Public Health 2016; 45(5): 558.

14. Mitra S, Rennie J. Neonatal jaundice: Aetiology, diagnosis and treatment. Br J Hosp Med 2017; 78(12): 699-704. 
15. Roy-Chowdhury J, Roy-Chowdhury N, Jansen PL. Bilirubin metabolism and its disorders. In: Zakim and Boyer's hepatology. Elsevier Inc.; 2006, p. 1449-85.

16. Kumar P, Murki S, Malik GK, Chawla D, Deorari AK, Karthi N, et al. Light-emitting diodes versus compact fluorescent tubes for phototherapy in neonatal jaundice: A multi-center randomized controlled trial. Indian Pediatr 2010; 47(2): 131-7.

17. Keppler D. The roles of MRP2, MRP3, OATP1B1, and OATP1B3 in conjugated hyperbilirubinemia. Drug Metab Dispos 2014; 42(4): 561-5.

18. Singh A, Jialal I. Unconjugated hyperbilirubinemia 2019. In: StatPearls [Internet]. Treasure Island (FL). StatPearls Publishing; 2021. Available from: https://www.ncbi.nlm.nih.gov/books/NBK549796/.

19. Balram C, Sabapathy K, Fei G, Khoo KS, Lee EJ. Genetic polymorphisms of UDP-glucuronosyltransferase in Asians: UGT1A1* 28 is a common allele in Indians. Pharmacogenet Genomics 2002; 12(1): 81-3.

20. Boo N-Y, Sin S, Chee S-C, Mohamed M, Ahluwalia AK, Ling MM-M, et al. Genetic factors and delayed TSB monitoring and treatment as risk factors associated with severe hyperbilirubinemia in term neonates admitted for phototherapy. J Trop Pediatr 2020; 66(6): 569-82.

21. Huang M-J, Lin Y-C, Liu K, Chang P-F, Huang C-S. Effects of variation status and enzyme activity for UDPglucuronosyltransferase 1A1 gene on neonatal hyperbilirubinemia. Pediatr Neonatol 2020; 61(5): 506-12.

22. Leung AK, Sauve RS. Breastfeeding and breast milk jaundice. J R Soc Health 1989; 109(6): 213-7.

23. Visentin M, Stieger B, Merz M, Kullak-Ublick GA. Octreotide inhibits the bilirubin carriers organic anion transporting polypeptides $1 \mathrm{~B} 1$ and $1 \mathrm{~B} 3$ and the multidrug resistance-associated protein 2. J Pharmacol Exp Ther 2015; 355(2): 145-51.

24. Gondal B, Aronsohn A. Biliary interventions: A systematic approach to patients with jaundice. In: Seminars in interventional radiology. Thieme Medical Publishers; 2016, p. 253.

25. Lapham K, Novak J, Marroquin LD, Swiss R, Qin S, Strock CJ, et al. Inhibition of hepatobiliary transport activity by the antibacterial agent fusidic acid: Insights into factors contributing to conjugated hyperbilirubinemia/cholestasis. Chem Res Toxicol 2016; 29(10): 1778-88.

26. Ma G, Zhang Y, Chen W, Tang Z, Xin X, Yang P, et al. Inhibition of human UGT1A1-mediated bilirubin glucuronidation by polyphenolic acids impact safety of popular salvianolic acid A/B-containing drugs and herbal products. Mol Pharm 2017; 14(9): 2952-66.

27. Chiddarwar AS, D'Silva SZ, Colah RB, Ghosh K, Mukherjee MB. Genetic variations in bilirubin metabolism genes and their association with unconjugated hyperbilirubinemia in adults. Ann Hum Genet 2017; 81(1): 11-9.

28. Shad MA, Haq N, Tanzila R, Ahmad HB, Mazhar H. Diagnostic criteria and contributors to Gilbert's syndrome. J Med Plants Res 2012; 6(28): 4467-74.

29. Wagner K-H, Shiels RG, Lang CA, Seyed Khoei N, Bulmer AC. Diagnostic criteria and contributors to Gilbert's syndrome. Crit Rev Clin Lab Sci 2018; 55(2): 129-39.

30. Lee C, Lee SM, Namgung R. Bilirubin metabolism and bilirubin encephalopathy. Neonatal Med 2013; 20(3): 268-75.

31. Roca L, Calligaris S, Wennberg RP, Ahlfors CE, Malik SG, Ostrow JD, et al. Factors affecting the binding of bilirubin to serum albumins: Validation and application of the peroxidase method. Pediatr Res 2006; 60(6): $724-8$.

32. Andreu Y, Galbán J, de Marcos S, Castillo JR. Determination of direct-bilirubin by a fluorimetric-enzymatic method based on bilirubin oxidase. Fresenius J Anal Chem 2000; 368(5): 516-21.

33. Westwood A. The analysis of bilirubin in serum. Ann Clin Biochem 1991; 28(2): 119-30.

34. Klemm J, Prodromidis MI, Karayannis MI. An enzymic method for the determination of bilirubin using an oxygen electrode. Electroanal Int J Devoted Fundam Pract Asp Electroanal 2000; 12(4): 292-5. 
35. Birch MJ. Practical clinical biochemistry, Volume 1 by Varley H, Gowenlock AH, Bell M. London: Heinemann; 1980, pp 1277. Wiley Online Library; 1982.

36. Laeeq A, Yasin M, Chaudhry AR. Transcutaneous bilirubinometry-clinical application. J-Pak Med Assoc 1993; 43: 28.

37. McEwen M, Reynolds KJ. Noninvasive detection of bilirubin using pulsatile absorption. Australas Phys Eng Sci Med 2006; 29(1): 78-83.

38. Adachi S, Uesugi T, Kamisaka K. Study of bilirubin metabolism by high-performance liquid chromatography: stability of bilirubin glucuronides. Arch Biochem Biophys 1985; 241(2): 486-93.

39. Darch M. Role of the cytochrome P450 2A5 in bilirubin metabolism and clearance in C57BL/6 mice. [PhD Thesis]; 2016.

40. Costarino AT, Ennever JF, Baumgart S, Speck WT, Paul M, Polin RA. Bilirubin photoisomerization in premature neonates under low-and high-dose phototherapy. Pediatrics 1985; 75(3): 519-22.

41. Agati G, Fusi F, Pratesi S, Galvan P, Donzelli GP. Bilirubin photoisomerization products in serum and urine from a Crigler-Najjar type I patient treated by phototherapy. J Photochem Photobiol B 1998; 47(2-3): 181-9.

42. Stephen AI, Ubwa ST, Igbum OG, Hati SS. Analytical methods comparison for the determination of bilirubin in blood samples of neonates. Adv Anal Chem 2017; 7(1): 1-6.

43. Kazmierczak SC, Robertson AF, Catrou PG, Briley KP, Kreamer BL, Gourley GR. Direct spectrophotometric method for measurement of bilirubin in newborns: comparison with HPLC and an automated diazo method. Clin Chem 2002; 48(7): 1096-7.

44. Pichon J-BL, Riordan SM, Watchko J, Shapiro SM. The neurological sequelae of neonatal hyperbilirubinemia: definitions, diagnosis and treatment of the kernicterus spectrum disorders (KSDs). Curr Pediatr Rev 2017; 13(3): 199-209.

45. Usman F, Diala UM, Shapiro S, LePichon J-B, Slusher TM. Acute bilirubin encephalopathy and its progression to kernicterus: current perspectives. Res Rep Neonatol 2018; 8: 33.

46. Shapiro SM. Definition of the clinical spectrum of kernicterus and bilirubin-induced neurologic dysfunction (BIND). J Perinatol 2005; 25(1): 54-9.

47. van Imhoff DE, Cuperus FJ, Dijk PH, Tiribelli C, Hulzebos CV. Kernicterus, bilirubin induced neurological dysfunction and new treatments for unconjugated hyperbilirubinemia. In: Neonatology. Springer; 2012, p. 621-8.

48. Onishi S, Isobe K, Itoh S, Manabe M, Sasaki K, Fukuzaki R, et al. Metabolism of bilirubin and its photoisomers in newborn infants during phototherapy. J Biochem (Tokyo) 1986; 100(3): 789-95.

49. Rehak NN, Cecco SA, Hortin GL. Photolysis of bilirubin in serum specimens exposed to room lighting. Clin Chim Acta Int J Clin Chem 2008; 387(1-2): 181.

50. Hansen TWR, Tommarello S. Effect of phenobarbital on bilirubin metabolism in rat brain. Neonatology 1998; 73(2): 106-11.

51. Soltys PJ, Mullon C, Langer R. Oral treatment for jaundice using immobilized bilirubin oxidase. Artif Organs 1992; 16(4): 331-5

52. Shad MA, Nawaz H, Rehman T, Ikram N, others. Determination of some biochemicals, phytochemicals and antioxidant properties of different parts of Cichorium intybus L.: A comparative study. J Anim Plant Sci 2013; 23(4): 1060-6.

53. Moghadamtousi SZ, Fadaeinasab M, Nikzad S, Mohan G, Ali HM, Kadir HA. Annona muricata (Annonaceae): A review of its traditional uses, isolated acetogenins and biological activities. Int J Mol Sci 2015; 16(7): $15625-58$.

54. Zhang L, Yuan B, Wang H, Gao Y. Therapeutic effect of Agaricus brasiliensis on phenylhydrazine-induced neonatal jaundice in rats. BioMed Res Int 2015; 2015. 
55. Abbasi AM, Khan MA, Ahmad M, Zafar M, Khan H, Muhammad N, et al. Medicinal plants used for the treatment of jaundice and hepatitis based on socio-economic documentation. Afr J Biotechnol 2009; 8(8).

56. Patra K, Storfer-Isser A, Siner B, Moore J, Hack M. Adverse events associated with neonatal exchange transfusion in the 1990s. J Pediatr 2004; 144(5): 626-31.

57. Badiee Z. Exchange transfusion in neonatal hyperbilirubinaemia: Experience in Isfahan, Iran. Singapore Med J 2007; 48(5): 421.

58. Murki S, Kumar P. Blood exchange transfusion for infants with severe neonatal hyperbilirubinemia. In: Seminars in perinatology. Elsevier; 2011. p. 175-84.

59. Bambauer R, El-Saadi R, Graf N, Jesberger HJ, Limbach HG, Cordes H. Plasmapheresis in newborns with hyperbilirubinemia. Artif Organs 1992; 16(5): 472-6.

60. Keklik M, Sivgin S, Kaynar L, Pala C, Solmaz M, Cetin M, et al. Treatment with plasma exchange may serve benefical effect in patients with severe hyperbilirubinemia: a single center experience. Transfus Apher Sci 2013; 48(3): 323-6.

61. Broux B, Lefere L, Deprez P, van Loon G. Plasma exchange as a treatment for hyperbilirubinemia in 2 foals with neonatal isoerythrolysis. J Vet Intern Med 2015; 29(2): 736.

62. Schauer R, Lang T, Zimmermann A, Stangl M, Da Silva L, Schildberg FW, et al. Successful liver transplantation of two brothers with crigler-najjar syndrome type 1 using a single cadaveric organ. Transplantation 2002; 73(1): 67-9.

63. Dhawan A, Mitry RR, Hughes RD. Hepatocyte transplantation for liver-based metabolic disorders. J Inherit Metab Dis 2006; 29(2): 431-5.

64. Roy-Chowdhury N, Kadakol A, Sappal BS, Thummala NR, Ghosh SS, Lee S-W, et al. Gene therapy for inherited hyperbilirubinemias. J Perinatol 2001; 21(1): S114-8.

65. van Dijk R, Beuers U, Bosma PJ. Gene replacement therapy for genetic hepatocellular jaundice. Clin Rev Allergy Immunol 2015; 48(2-3): 243-53.

66. Arnolda G, Chien TD, Hayen A, Hoi NTX, Maningas K, Joe P, et al. A comparison of the effectiveness of three LED phototherapy machines, single-and double-sided, for treating neonatal jaundice in a low resource setting. PLoS One 2018; 13(10): e0205432.

67. Montealegre A, Charpak N, Parra A, Devia C, Coca I, Bertolotto AM. Effectiveness and safety of two phototherapy devices for the humanised management of neonatal jaundice. An Pediatría Engl Ed 2020; 92(2): 79-87.

68. Ergaz Z, Arad I. Intravenous immunoglobulin therapy in neonatal immune hemolytic jaundice. J Perinat Med-Off J WAPM 1993; 21(3): 183-7.

69. Alpay F, Sarici SU, Okutan V, Erdem G, Özcan O, Gökçay E. High-dose intravenous immunoglobulin therapy in neonatal immune haemolytic jaundice. Acta Paediatr 1999; 88(2): 216-9.

70. Girish G, Chawla D, Agarwal R, Paul VK, Deorari AK. Efficacy of two dose regimes of intravenous immunoglobulin in $\mathrm{Rh}$ hemolytic disease of newborn-a randomized controlled trial. Indian Pediatr 2008; $45(8)$ : 653.

71. Demirel G, Akar M, Celik IH, Erdeve O, Uras N, Oguz SS, et al. Single versus multiple dose intravenous immunoglobulin in combination with LED phototherapy in the treatment of $\mathrm{ABO}$ hemolytic disease in neonates. Int J Hematol 2011; 93(6): 700-3.

72. Schulz S, Wong RJ, Vreman HJ, Strevenson DK. Metalloporphyrins-an update. Front Pharmacol 2012; 3: 68.

73. Fujioka K, Kalish F, Wong RJ, Stevenson DK. Inhibition of heme oxygenase activity using a microparticle formulation of zinc protoporphyrin in an acute hemolytic newborn mouse model. Pediatr Res 2016; 79(2): 251-7.

74. Maisels MJ, Yang H. Tin-mesoporphyrin in the treatment of refractory hyperbilirubinemia due to Rh incompatibility. J Perinatol 2012; 32(11): 899-900. 
75. Fallah R, Islami Z, Lotfi SR. Single dose of $50 \mathrm{mg} / \mathrm{kg}$ clofibrate in jaundice of healthy term neonates: Randomised clinical trial of efficacy and safety. Indian J Pediatr 2012; 79(2): 194-7.

76. Al-Banna SM, Riad AN, Anis SS. The effect of fenofibrate and antioxidant vitamins [D, E and C] in treatment of uncomplicated neonatal hyperbilirubinemia. Ann Neonatol J 2020; 2(1): 37-48.

77. Quidde J, Azémar M, Bokemeyer C, Arnold D, Stein A. Treatment approach in patients with hyperbilirubinemia secondary to liver metastases in gastrointestinal malignancies: A case series and review of literature. Ther Adv Med Oncol 2016; 8(3): 144-52.

78. Wu R, Feng S, Han M, Caldwell P, Liu S, Zhang J, et al. Yinzhihuang oral liquid combined with phototherapy for neonatal jaundice: A systematic review and meta-analysis of randomized clinical trials. BMC Complement Altern Med 2018; 18(1): 228.

79. Faal G, Masjedi HK, Sharifzadeh G, Kiani Z. Efficacy of zinc sulfate on indirect hyperbilirubinemia in premature infants admitted to neonatal intensive care unit: A double-blind, randomized clinical trial. BMC Pediatr 2020; 20(1): 1-7.

80. Kassem LM, Abdelrahim M, Naguib HF. Investigating the efficacy and safety of silymarin in management of hyperbilirubinemia in neonatal jaundice. Med Sci 2013; 2(2): 575-90.

81. Lei M, Liu T, Li Y, Liu Y, Meng L, Jin C. Effects of massage on newborn infants with jaundice: A metaanalysis. Int J Nurs Sci 2018; 5(1): 89-97.

82. Wang L, Shuai T, Wang Y-Y, Cao H. The effect of traditional Chinese medicine washing combined with massage for neonatal jaundice: A meta-analysis. TMR Integr Nurs 2018; 1(2): 36-44.

83. Slusher TM, Olusanya BO, Vreman HJ, Wong RJ, Brearley AM, Vaucher YE, et al. Treatment of neonatal jaundice with filtered sunlight in Nigerian neonates: study protocol of a non-inferiority, randomized controlled trial. Trials 2013; 14(1): 446.

84. Negi R, Sorte DY, Gomati B. Effect of white reflecting curtains on neonatal jaundice. Int J Nurs Educ 2015; 7(4): 147-52.

85. Pratesi S, Di Fabio S, Bresci C, Di Natale C, Bar S, Dani C. Broad-spectrum light versus blue light for phototherapy in neonatal hyperbilirubinemia: A randomized controlled trial. Am J Perinatol 2015; 32(08): 779-84.

86. Zeng J, Wang S, Li Y, Li H, Luo Q, Huang Y, et al. Yinzhihuang oral liquid in the treatment of neonatal jaundice: A meta-analysis. Pharm Biol 2017; 55(1): 554-9.

87. Beiranvand S, Hosseinabadi R, Firouzi M, Almasian M, Anbari K. Impact of combined oral zinc sulfate and phototherapy on serum bilirubin levels in the term neonates with jaundice. Iran J Neonatol IJN 2018; 9(3): 20-5.

88. Boskabadi H, Mollaei MK, Zakerihamidi M, Mobarhan MG, Bagheri F. The effect of exchange transfusion on prooxidant-antioxidant balance in newborns Jaundice. Biomed Res Ther 2018; 5: 2119-29.

89. Colbourn T, Mwansambo C. Sunlight phototherapy for neonatal jaundice-time for its day in the sun? Lancet Glob Health 2018; 6(10): e1052-3.

90. Thakkar D, Verma A, Malgorzata R. G11 Phototherapy at home for the treatment of neonatal jaundice: An innovative, patient centered pilot project. Arch Dis Child 2019; 104(Suppl 2): A5.

91. Abdel-Aziz Ali SM, Mansour Galal S, Sror SM, Hussein O, Abd-El-Haseeb Ahmed A-E-HO, Hamed EA. Efficacy of oral agar in management of indirect hyperbilirubinemia in full-term neonates. J Matern Fetal Neonatal Med 2020; 1-6.

92. Nizam MA, Alvi AS, Hamdani MM, Lalani AS, Sibtain SA, Bhangar NA. Efficacy of double versus single phototherapy in treatment of neonatal jaundice: A meta-analysis. Eur J Pediatr 2020; 179(6): 865-74.

93. Rahideh ST, Saadati A, Rahmati N, Azadeh F, Janani L, Shidfar F. The effect of vitamin C supplementation in the last month of pregnancy on neonatal bilirubin levels; A double-blind randomized clinical trial. Complement Ther Med 2020; 102359. 